\title{
Does brand posting behaviour influence follower engagement on Instagram?
}

\author{
Carmen BALAN \\ The Bucharest University of Economic Studies, Bucharest, Romania \\ carmen.balan@mk.ase.ro
}

\begin{abstract}
The Instagram application captured the attention of hundreds of millions of users. The goal of this paper was to study whether there is a statistically significant relationship between the posting behaviour of corporate retail brands on Instagram and follower engagement. The proxy variables used to describe the posting behaviour were: number of days with posts, number of posts and existence of calls to action within posts. The proxy variables for engagement were the number of likes, as well as the sum of likes and comments for each post. The study referred to the Instagram activity of the top fifty global specialty retailers. Lately, the researchers' interest in social media grew substantially. In contrast, the studies relative to the posting behaviour of companies on Instagram are rather scarce. At present, scientific research on this topic is in an preliminary state. In addition, there are no published findings of scientific research on the use of Instagram by top global specialty retailers. The paper aimed to answer the following research questions: (a) "Is posting on Instagram a common behaviour of the top fifty global specialty retailers?"; (b) "How active are these companies in posting own photo and video content?"; (c) "Are there statistically significant relationships between the variables describing the posting behaviour and those reflecting the follower engagement?". The data were collected by monitoring verified badge Instagram accounts of the top fifty global specialty retailers. The t test was applied on data from the online study of 612 posts. Findings reveal statistical significant relationships between the analysed variables. There is a strong correlation between the number of posts and engagement. To the best of our knowledge, this article is the first to approach this topic. As a direct implication for retailers, an intense posting activity may lead to an increased engagement of followers.
\end{abstract}

Keywords: Instagram, top global specialty retailers, photo and video posts, engagement, followers.

\section{Introduction}

Since its initial release in October 2010, Instagram evolved rapidly from a social media novelty into a marketing communication tool. In December 2016, Instagram counted more than 600 million users (Instagram, 2016, 15 December).

The purpose of the research presented in this paper was to study whether there are statistically significant relationships between the posting behaviour of corporate retail brands on Instagram and the follower engagement with the photo or video posts. In this research, the proxy variables used to describe the posting behaviour were the following: number of days with posts and number of posts (made by retailer during a month), as well as the existence of one or more calls to action (within the text or visual component of the post). The study focused on the Instagram activity of the top fifty global specialty retailers.

The research started from the initial hypotheses according to which there are no statistically significant relationships between each of the variables describing the posting behaviour and each of the variables reflecting engagement. The null hypotheses were based on the absence of previous research findings revealing the existence of correlations and statistically significant relationships. 
The research consisted in the virtual monitoring of the verified badge Instagram accounts of the top fifty global specialty retailers. The chronological perspective relied on two approaches. The former was a cross-section investigation of the Instagram accounts on 22 January 2017. The latter was a longitudinal study of the posting behaviour of the retailers during the period 1-31 December 2016.

To the best of our knowledge, this research is the first to approach the topic of the statistically significant relationships between posting behaviour of top global specialty retailers on Instagram and follower engagement.

\section{Instagram: present state of scientific research}

Since 2010, a multi-faceted view of Instagram has evolved, due to the research findings from various areas of study. The domains which contributed the most to the development of the research literature relative to Instagram are the following: computer science, electrical and electronic engineering and computer science. Besides these, some other domains made several initial strides in studying Instagram. Such examples are research on: communication, business, education, psychology and health.

On 10 February 2017, the Thomson Reuters Web of Science listed 82 documents with titles that included the word "Instagram". On the same date, the database listed 329 documents (out of which 157 articles) that approached the topic "Instagram".

The above-mentioned numbers of documents listed in Web of Science seems large enough to represent a solid grounding for further research on Instagram. However, a deeper analysis uncovers that many of the existing studies focus on the posting behaviour of consumers, adults or teens, men or women. The research topics relative to the posting behaviour of companies and brands, as well as to its impact on follower engagement were rather neglected until present.

One of the extremely few extant studies refers to the impact of the type of posting on the Facebook and Instagram metrics (Coelho, de Oliveira and de Almeida, 2016). Another study focused on a comparative analysis on how fashion brand use different social networks such as Twitter and Instagram (Manikonda, Venkatesan, Kambhampati, and Li, 2015.).

The present status of research relative to how companies and brands use the Instagram application indicates significant potential for further development. The findings of such research projects may support the endeavour of marketers to build customer relationships and enhance brand equity.

\section{Methodology}

The goal of this research was to study whether there are statistically significant relationships between the variables describing the posting behaviour on Instagram of the top fifty global specialty retailers and the variables reflecting follower engagement with the photo or video posts. The main research questions were the following: (a) "Is posting on Instagram a common behaviour of the top fifty global specialty retailers?"; (b) "How active are these companies in posting own photo and video content?"; (c) "Are there statistically significant relationships between the variables describing the posting behaviour and those reflecting the follower engagement?". 
Data collection consisted in three distinct stages. Firstly, the top fifty global specialty retailers were identified. The ranking of top specialty retailers was established according to the revenue generated during the fiscal year 2015 (Deloitte Touche Tohmatsu, 2017). Secondly, data on their Instagram accounts were obtained. Only the Instagram accounts with a verified badge were considered for this research, because only such badge confirms that the Instagram account authentically belongs to a specific retailer from our list. Information on posts and followers of the top fifty global specialty retailers were gathered by direct observation on 22 January 2017. Thirdly, specific and detailed information on the posts of the top twenty-three global specialty retailers during the period 1-31 December 2016 were collected. In this stage, the observation focused on precise data relative to the day of posting, type of posts (photo or video) made by the retailer, number of likes and comments for each post, existence of an explicit or implicit call to action (presented in the text or in the visual component of the post).

Several methodological details relative to the Instagram accounts that were considered for virtual monitoring were clarified at the beginning of the research process. The need for such clarifications was generated by the fact that some of the top global retailers own more than one Instagram account with verified badge. The multiple accounts are related either to the different retail brands existing in their portfolios or to the brand presence in more than one country. Within the list of top fifty global specialty retailers, this is the case of the IKEA Group (with eight accounts, out of which the USA account was selected), TJX Companies (with two major retail chains of which TJ Maxx was chosen), Inditex S.A. (with several retail chains of which Zara was selected), H \& M Hennes \& Mauritz $\mathrm{AB}$ (hm account was selected over hm_home account), L Brands Inc. (with five retail brands of which La Senza was selected) and Décathlon S.A. (with eight verified badge accounts, out of which the account from Spain was selected). In such cases, only the account with the highest awareness or with the highest number of followers was selected for analysis. This approach was preferred instead of summing up the figures corresponding to several Instagram accounts belonging to one retailer, in order to avoid the double counting of followers that may register simultaneously with more than one account of the same company/brand.

The data collected during the direct monitoring of the verified badge Instagram accounts were registered in a database that allowed the clear and accurate presentation of the situation of each top twenty-three global specialty retailer that owned such an account in December 2016. For each retailer, the database included the series of values corresponding to the studied variables. Data processing followed the completion of data registration. The findings of this research conducted in the online environment are presented hereinafter.

\section{Research findings}

The main research findings corresponding to the three research questions are presented hereinafter.

\section{Use of Instagram}

The first research question was formulated as follows: "Is posting on Instagram a common behaviour of the top fifty global specialty retailers?". 
The answer to this question is negative. At present, less than half of the top fifty global specialty retailers use the Instagram channel as part of their communication strategy. According to the data collected online through observation, only 23 of these top fifty retailers are present on Instagram with verified badge accounts (AutoZone, Inc., 2017, 22 January; Best Buy Co., Inc., 2017, 22 January; Canadian Tire Corporation, Limited, 2017, 22 January; CVS Health Corporation, 2017, 22 January; Décathlon S.A., 2017, 22 January; Dick's Sporting Goods, Inc., 2017, 22 January; dm-drogerie markt GmbH + Co. KG., 2017, 22 January; Foot Locker, Inc. , 2017, 22 January; GameStop Corp., 2017, 22 January; H \& M Hennes \& Mauritz AB., 2017, 22 January; Inditex, S.A., 2017, 22 January; Kering S.A., 2017, 22 January; Lowe's Companies, Inc., 2017, 22 January; L Brands, Inc., 2017, 22 January; LVMH Moët Hennessy-Louis Vuitton S.A., 2017, 22 January; PetSmart, Inc., 2017, 22 January; Rite Aid Corporation, 2017, 22 January; Staples, Inc., 2017, 22 January; The Gap, Inc., 2017, 22 January; The Home Depot, Inc., 2017, 22 January; The IKEA Group; 2017, 22 January; The TJX Companies, Inc., 2017, 22 January; Walgreens Boots Alliance, Inc., 2017, 22 January). These retailers are presented in Table 1.

Table 1. Top 23 global specialty retailers that own verified badge Instagram accounts ${ }^{1}$

\begin{tabular}{|c|l|c|c|c|c|}
\hline Rank ${ }^{2}$ & \multicolumn{1}{|c|}{ Company } & Specialty & $\begin{array}{c}\text { Fiscal } \\
\text { Country of } \\
\text { origin } \\
\mathbf{2 0 1 5} \\
\text { retail } \\
\text { revenue } \\
\text { (US\$M) }\end{array}$ & $\begin{array}{c}\text { Number } \\
\text { of } \\
\text { countries } \\
\text { of } \\
\text { operation }\end{array}$ \\
\hline 1 & $\begin{array}{l}\text { Walgreens Boots Alliance, } \\
\text { Inc. (formerly Walgreen Co.) }\end{array}$ & $\begin{array}{c}\text { Drug Store/ } \\
\text { Pharmacy }\end{array}$ & US & 89,631 & 10 \\
\hline 2 & The Home Depot, Inc. & $\begin{array}{c}\text { Home } \\
\text { Improvement }\end{array}$ & US & 88,519 & 4 \\
\hline 3 & CVS Health Corporation & $\begin{array}{c}\text { Drug Store/ } \\
\text { Pharmacy }\end{array}$ & US & 72,007 & 3 \\
\hline 4 & Lowe's Companies, Inc. & $\begin{array}{c}\text { Home } \\
\text { Improvement }\end{array}$ & US & 59,074 & 4 \\
\hline 5 & Best Buy Co., Inc. & Electronics & US & 39,528 & 4 \\
\hline 6 & $\begin{array}{l}\text { The IKEA Group (INGKA } \\
\text { Holding B.V.) }\end{array}$ & Other & Netherlands & 37,105 & 28 \\
\hline 7 & The TJX Companies, Inc. & $\begin{array}{c}\text { Apparel/ } \\
\text { Footwear }\end{array}$ & US & 30,945 & 10 \\
\hline 8 & Rite Aid Corporation & $\begin{array}{c}\text { Drug Store/ } \\
\text { Pharmacy }\end{array}$ & US & 26,866 & 1 \\
\hline 9 & $\begin{array}{l}\text { LVMH Moët Hennessy-Louis } \\
\text { Vuitton S.A. }\end{array}$ & Other & France & 25,605 & 80 \\
\hline 10 & Inditex, S.A. & $\begin{array}{c}\text { Apparel/ } \\
\text { Footwear }\end{array}$ & Spain & 23,0743 & 88 \\
\hline 11 & H \& M Hennes \& Mauritz AB & $\begin{array}{c}\text { Apparel/ } \\
\text { Footwear }\end{array}$ & Sweden & $21,678^{3}$ & 61 \\
\hline 12 & The Gap, Inc. & $\begin{array}{c}\text { Apparel/ } \\
\text { Footwear }\end{array}$ & US & 15,797 & 56 \\
\hline 13 & L Brands, Inc. & Apparel/ & US & 12,1543 & 80 \\
\hline 16 & Ataples, Inc. & OutoZtwer & US & 10,720 e & 13 \\
\hline 16 & Décathlon S.A. & Other & France & 10,108 & 30 \\
\hline
\end{tabular}

DOI: 10.1515/picbe-2017-0073, pp. 687-697, ISSN 2558-9652| Proceedings of the $11^{\text {th }}$ International Conference on Business Excellence 


\begin{tabular}{|c|l|c|c|c|c|}
17 & GameStop Corp. & Other & US & 9,364 & 15 \\
\hline 18 & $\begin{array}{l}\text { dm-drogerie markt GmbH }+ \\
\text { Co. KG }\end{array}$ & $\begin{array}{c}\text { Drug Store/ } \\
\text { Pharmacy }\end{array}$ & Germany & $9,299 \mathrm{e}$ & 12 \\
\hline 19 & $\begin{array}{l}\text { Canadian Tire Corporation, } \\
\text { Limited }\end{array}$ & Other & Canada & 8,6793 & 1 \\
\hline 20 & Foot Locker, Inc. & $\begin{array}{c}\text { Apparel/ } \\
\text { Footwear }\end{array}$ & US & 7,412 & 30 \\
\hline 21 & PetSmart, Inc. & Other & US & $7,300^{\mathrm{e}}$ & 3 \\
\hline 22 & Dick's Sporting Goods, Inc. & Other & US & 7,271 & 1 \\
\hline 23 & Kering S.A. & $\begin{array}{c}\text { Apparel/ } \\
\text { Footwear }\end{array}$ & France & 7,039 & 95 \\
\hline
\end{tabular}

PICBE | 691

Source: The list of companies with verified badge Instagram account is based on the author's own research. Note: 1 Situation on 22 January 2017. 2 Rank is based on the retail revenue corresponding to the fiscal year 2015. 3 Revenue includes wholesale and retail sales. e Estimates. Data on the retail revenue in the fiscal year 2015 and on the number of countries of operation is based on Deloitte Touche Tohmatsu, 2017.

The Instagram accounts are used by retailers to cross-promote one or more of the other online touchpoints such as: website, online/Instagram shop, another Instagram account, tumblr account and snapchat account. This is a strategy common to all the 23 top glob specialty retailers that have verified badge Instagram accounts.

\section{Posting photo and video content on Instagram}

The second and third research questions were the following: "How active are these companies in posting own photo and video content?".

Table 2 presents the number of posts of the top global specialty retailers that own verified badge Instagram account, respectively 23 retailers of the "Top 50".

Table 2. Number of posts and followers of the top 23 global specialty retailers that own verified badge Instagram accounts, on 22 January 2017

\begin{tabular}{|c|l|l|c|c|}
\hline Rank & \multicolumn{1}{|c|}{ Company } & \multicolumn{1}{|c|}{$\begin{array}{c}\text { Instagram account } \\
\text { studied }^{2}\end{array}$} & $\begin{array}{c}\text { Number } \\
\text { of posts }\end{array}$ & $\begin{array}{c}\text { Number of } \\
\text { followers } \\
\text { (thousands) }\end{array}$ \\
\hline 1 & $\begin{array}{l}\text { Walgreens Boots Alliance, Inc. } \\
\text { (formerly Walgreen Co.) }\end{array}$ & walgreens & 1,044 & 150 \\
\hline 2 & The Home Depot, Inc. & homedepot & 1,208 & 308 \\
\hline 3 & CVS Health Corporation & cvspharmacy & 109 & 37.1 \\
\hline 4 & Lowe's Companies, Inc. & loweshomeimprovement & 1,258 & 361 \\
\hline 5 & Best Buy Co., Inc. & bestbuy & 95 & 100 \\
\hline 6 & $\begin{array}{l}\text { The IKEA Group (INGKA Holding } \\
\text { B.V.) }\end{array}$ & ikeausa & 1,410 & 1,000 \\
\hline 7 & The TJX Companies, Inc. & tjmaxx & 1,497 & 774 \\
\hline 8 & Rite Aid Corporation & riteaid & 786 & 26.3 \\
\hline 9 & $\begin{array}{l}\text { LVMH Moët Hennessy-Louis } \\
\text { Vuitton S.A. }\end{array}$ & lvmh & 557 & 158 \\
\hline 10 & Inditex, S.A. & zara & 1,250 & 15,600 \\
\hline 11 & H \& M Hennes \& Mauritz AB & hm & 3,092 & 18,400 \\
\hline 12 & The Gap, Inc. & gap & 1,942 & 1,500 \\
\hline 13 & L Brands, Inc. & lasenza & 2,375 & 252 \\
\hline 14 & Staples, Inc. & staples & 368 & 35 \\
\hline
\end{tabular}




\begin{tabular}{|c|l|l|c|c|}
15 & AutoZone, Inc. & autozone & 203 & 13.6 \\
\hline 16 & Décathlon S.A. & decathlones & 1,103 & 79.2 \\
\hline 17 & GameStop Corp. & gamestop & 311 & 523 \\
\hline 18 & $\begin{array}{l}\text { dm-drogerie markt GmbH + Co. } \\
\text { KG }\end{array}$ & dm_deutschland & 910 & 1,000 \\
\hline 19 & $\begin{array}{l}\text { Canadian Tire Corporation, } \\
\text { Limited }\end{array}$ & canadiantire & 1,068 & 37.1 \\
\hline 20 & Foot Locker, Inc. & footlocker & 5,079 & 6,400 \\
\hline 21 & PetSmart, Inc. & petsmart & 1,398 & 287 \\
\hline 22 & Dick's Sporting Goods, Inc. & dickssportinggoods & 1,447 & 262 \\
\hline 23 & Kering S.A. & kering_official & 420 & 19.2 \\
\hline
\end{tabular}

PICBE $\mid 692$

Source: Based on the author's research of the Instagram accounts. Note: 1 Rank is based on the retail revenue corresponding to the fiscal year 2015. 2 Instagram account identified based on author's own research. 3 Number of posts and followers displayed on the Instagram accounts studied on 22 January 2017.

The number of posts ranges between a minimal value of 95 in the case of Best Buy Co., Inc. and the maximum of 5,079 scored by Foot Locker, Inc. The number of followers varies from 13,600 in the case of Autozone, Inc. to 18,400,000 achieved by H \& M Hennes \& Mauritz AB.

\section{Statistical significance of relationships: first testing stage}

The third research question was the following: "Are there statistically significant relationships between the variables describing the posting behaviour and those reflecting the follower engagement?". The first stage consisted in the study of the correlation between the total number of posts corresponding to the verified badge Instagram account of each global specialty retailer and the number of followers of that account. Further, the t test was applied.

The Pearson coefficient of correlation was calculated (Malhotra, 2010) based on the formula (1):

$$
\mathrm{r}=\frac{\sum_{\mathrm{i}=1}^{\mathrm{n}}\left(\mathrm{X}_{\mathrm{i}}-\bar{X}\right)\left(\mathrm{Y}_{\mathrm{i}}-\bar{Y}\right)}{\sqrt{\sum_{i=1}^{n}\left(\mathrm{X}_{\mathrm{i}}-\bar{X}\right)^{2} \sum_{i=1}^{n}\left(\mathrm{Y}_{\mathrm{i}}-\overline{\mathrm{Y}}\right)^{2}}}
$$

In this formula, the symbols have the following meanings: $r=$ Pearson coefficient of correlation; $i=$ number of top specialty retailers from "Top 50" that have verified badge Instagram accounts; $X_{i}=$ number of posts corresponding to the Instagram account of a specific retailer; $\bar{X}=$ average number of posts for the accounts of the 23 retailers; $Y_{i}=$ number of followers corresponding to the Instagram account of a specific retailer; $\bar{Y}=$ average number of followers of the accounts of the 23 retailers.

The data presented in table 2 and formula (1) leads to the value $r=0.4896$ of the Pearson coefficient of correlation.

The sign of the $r$ coefficient indicates there is a positive relationship between the number of photo and video posts made on Instagram by each top specialty retailer and the number of followers. The higher the number of posts, the higher the number the followers is and vice versa. The value of the coefficient shows a medium correlation between the two variables. 
This research also aimed to test the statistical significance of the relationship between the number of posts and the number of followers. According to the null hypothesis, the relationship is not statistically significant. The alternative hypothesis states the opposite. The test statistic is:

$$
\mathrm{t}_{\mathrm{c}}=\mathrm{r} * \sqrt{\left[\frac{n-2}{1-r^{2}}\right]}
$$

In formula (2), symbols have the following meanings: $t=$ the calculated value of the $t$ test; $n-2=$ number of degrees of freedom; $r=$ Pearson coefficient of correlation. The calculated value of $t$ is $t_{c}=2.57$.

For $\alpha=0.05$ and the number of degrees of freedom of $n-2=21$, the critical value of $t$ for a two-tailed test is 1.7207 . Thus, the calculated value is greater than the critical value $(2.57>1.7207)$ and the null hypothesis is not accepted. The conclusion is there is a significant relationship between the number of posts made by top specialty retailers and the number of followers of their Instagram accounts.

\section{Statistical significance of relationships: second testing stage}

In the second stage, the $t$ test was applied based on longitudinal research data relative to 612 posts made by retailers on Instagram in December 2016.

The research achieved on the verified badge Instagram accounts of the top 23 global specialty retailers led to the data presented in the table 3 . The online research consisted in the monitoring of the accounts during the entire month of December 2016. Posting behaviour was reflected by variables like: number of days with posts (number of days within the month of December 2016, in which the retailers posted photo or video content), number of posts (made by each retailer in the month of December 2016) and the existence of a call to action associated with the post (in the text or in the visual content). People engagement with the posts was reflected by the following variables: number of likes and number of comments.

Table 3. Posting behaviour of the top 23 global specialty retailers on their own verified badge Instagram accounts, and engagement figures, during the period 1-31 December 2016

\begin{tabular}{|l|c|c|c|c|c|}
\hline \multicolumn{1}{|c|}{ Top specialty retailer } & $\begin{array}{c}\text { Number } \\
\text { of days } \\
\text { with posts }\end{array}$ & $\begin{array}{c}\text { No. of } \\
\text { posts }\end{array}$ & No. of likes & $\begin{array}{c}\text { No. of } \\
\text { com- } \\
\text { ments }\end{array}$ & $\begin{array}{c}\text { Number } \\
\text { of posts } \\
\text { inclu- } \\
\text { ding } \\
\text { call to } \\
\text { action }\end{array}$ \\
\hline $\begin{array}{l}\text { Walgreens Boots Alliance, Inc. } \\
\text { (formerly Walgreen Co.) }\end{array}$ & 24 & 40 & 36,730 & 121 & 34 \\
\hline The Home Depot, Inc. & 11 & 11 & 43,320 & 232 & 9 \\
\hline CVS Health Corporation & 15 & 15 & 6,300 & 109 & 10 \\
\hline Lowe's Companies, Inc. & 19 & 19 & 50,096 & 658 & 17 \\
\hline Best Buy Co., Inc. & 5 & 5 & 4,768 & 155 & 1 \\
\hline $\begin{array}{l}\text { The IKEA Group (INGKA Holding } \\
\text { B.V.) }\end{array}$ & 23 & 31 & 178,014 & 826 & 23 \\
\hline
\end{tabular}




\begin{tabular}{|c|c|c|c|c|c|}
\hline The TJX Companies, Inc. & 12 & 12 & 46,593 & 414 & 12 \\
\hline Rite Aid Corporation & 23 & 28 & 3,240 & 69 & 13 \\
\hline $\begin{array}{l}\text { LVMH Moët Hennessy-Louis } \\
\text { Vuitton S.A. }\end{array}$ & 5 & 5 & 10,244 & 149 & 3 \\
\hline Inditex, S.A. & 17 & 19 & $1,434,305$ & 8,508 & 4 \\
\hline H \& M Hennes \& Mauritz AB & 31 & 93 & $11,116,729$ & 32,136 & 46 \\
\hline The Gap, Inc. & 24 & 30 & 391,578 & 204,130 & 22 \\
\hline L Brands, Inc. & 31 & 53 & 167,322 & 2,219 & 52 \\
\hline Staples, Inc. & 5 & 5 & 1,302 & 38 & 1 \\
\hline AutoZone, Inc. & 4 & 4 & 622 & 23 & 1 \\
\hline Décathlon S.A. & 30 & 30 & 19,707 & 99 & 24 \\
\hline GameStop Corp. & 9 & 9 & 54,745 & 619 & 9 \\
\hline $\begin{array}{l}\text { dm-drogerie markt GmbH + Co. } \\
\text { KG }\end{array}$ & 16 & 17 & 446,477 & 21,954 & 13 \\
\hline Canadian Tire Corporation, Ltd. & 19 & 24 & 5,648 & 117 & 8 \\
\hline Foot Locker, Inc. & 30 & 114 & $5,167,534$ & 33,947 & 24 \\
\hline PetSmart, Inc. & 29 & 32 & 136,114 & 1,059 & 7 \\
\hline Dick's Sporting Goods, Inc. & 6 & 7 & 14,358 & 13,313 & 1 \\
\hline Kering S.A. & 4 & 9 & 5,104 & 90 & 0 \\
\hline Total & 392 & 612 & $19,340,850$ & 320,985 & 324 \\
\hline
\end{tabular}

Source: Based on the author's research of the posting behaviour of the top 23 global specialty retailers on their verified badge Instagram accounts, during the period 1-31 December 2016.

The Pearson coefficient of correlation - based on the formula (1) - was also applied to study the relation between the variables reflecting the posting behaviour of retailers and the variables reflecting people engagement. The values of this coefficient are presented in table 4.

Table 4. The values of the Pearson coefficient for each potential correlation between the variables relative to posting behaviour and to engagement

\begin{tabular}{|l|c|c|}
\hline \multirow{2}{*}{$\begin{array}{c}\text { Variables relative to } \\
\text { posting behaviour }\end{array}$} & \multicolumn{2}{c|}{ Variables relative to engagement } \\
\cline { 2 - 3 } & Number of likes (Y1) & $\begin{array}{c}\text { Number of likes and } \\
\text { comments (Y2) }\end{array}$ \\
\hline Number of days with posts (X1) & $\mathrm{r}_{11}=0.4297$ & $\mathrm{r}_{12}=0.4326$ \\
\hline Number of posts (X2) & $\mathrm{r}_{21}=0.7803$ & $\mathrm{r}_{22}=0.7815$ \\
\hline Existence of a call to action (X3) & $\mathrm{r}_{31}=0.5029$ & $\mathrm{r}_{32}=0.5048$ \\
\hline
\end{tabular}

Source: Based on the data collected through the monitoring of the verified badge Instagram accounts of the top 23 global specialty retailers during the period 1-31 December 2016. Note: The value of the variable Y2 corresponding to a specific post is calculated as the sum of the number of likes and comments generated by that post.

All the Pearson coefficients of correlation from table 4 have positive values. The positive sign reveals direct relationships between variables. Consequently, the higher the values of the variables relative to the posting behaviour are, the higher the engagement is. The values of the correlation coefficients $r_{21}$ and $r_{22}$ show a relatively strong correlation between the number of posts and the engagement expressed as either number of likes or sum of likes and comments. The coefficients $r_{31}$ and $r_{32}$ indicate a medium correlation between the existence of a call to action and engagement. The lowest values of the coefficients were registered for the correlation between the number of days with posts and engagement. 
The data analysis also encompassed the testing of the statistical significance of the relationship between each variable of the posting behaviour and each variable of engagement. According to the null hypothesis, the relationship is not statistically significant, while the alternative hypothesis states the opposite. The test statistic is that presented in formula (3). Table 5 presents the calculated values of the $t$ test.

Table 5. The calculated values of the t test for each relation between the variables relative to posting behaviour and to engagement

\begin{tabular}{|l|c|c|}
\hline \multirow{2}{*}{$\begin{array}{c}\text { Variables relative to } \\
\text { posting behaviour }\end{array}$} & \multicolumn{2}{c|}{ Variables relative to engagement } \\
\cline { 2 - 3 } & Number of likes (Y1) & $\begin{array}{c}\text { Number of likes and } \\
\text { comments (Y2)* }\end{array}$ \\
\hline Number of days with posts (X1) & $\mathrm{t}_{11}=2.1807$ & $\mathrm{t}_{12}=2.1988$ \\
\hline Number of posts (X2) & $\mathrm{t}_{21}=5.7175$ & $\mathrm{t}_{22}=5.7401$ \\
\hline Existence of a call to action (X3) & $\mathrm{t}_{31}=2.6663$ & $\mathrm{t}_{32}=2.6798$ \\
\hline
\end{tabular}

Source: Based on the data collected through the monitoring of the verified badge Instagram accounts of the top 23 global specialty retailers during the period 1-31 December 2016. Note: The value of the variable Y2 corresponding to a specific post is calculated as the sum of the number of likes and comments generated by that post.

For $\alpha=0.05$ and the number of degrees of freedom of $n-2=21$, the critical value of $t$ for a two-tailed test is 1.7207. All the calculated values of the test are greater than the critical value. Thus, the null hypothesis is not accepted. Consequently, there are significant relationships between each of the three variables describing the posting behaviour and the two variables that reflect engagement. A special attention deserves the relation between the number of posts and engagement.

\section{Conclusions}

Research findings uncovered statistically significant relationships existing between the variables describing the posting behaviour of retailers and the variables related to follower engagement. The strongest correlation exists between the number of posts and the number of likes and respectively the sum of likes and comments.

This paper contributes to the scientific knowledge advancement in the field of research related to Instagram, by underlining the influence that posting behaviour of retailers has on follower engagement.

For further research, the implications of the findings of this paper consist in signalling the need for the investigation of relationships between other variables relative to posting behaviour and follower engagement. Examples of such variables are: day of the week when content is posted on Instagram, type of post (photo vs. video), number of posts per day, number of calls to action per post etc. Research may be extended in the field of the themes approached by posts and the impact of the various themes on the level of engagement.

Implications for managers are direct and significant. The more active a retailer will be in posting on Instagram, the higher the follower engagement in terms of likes and comments. The intense posting activity may have a positive impact on building relationships with customer communities and on the development of brand equity, especially among the young generations.

The marketers which did not grasp the potential of Instagram need more evidence to change their attitude. Future research initiatives may be instrumental in changing the 
perspective of marketers towards the market opportunity provided by this expanding community of more than 600 million Instagrammers.

\section{References}

AutoZone, Inc. (2017, 22 January). autozone. Retrieved from https://www.instagram.com/autozone/.

Best Buy Co., Inc. (2017, 22 January). bestbuy. Retrieved from https://www.instagram.com/bestbuy/.

Canadian Tire Corporation, Limited. (2017, 22 January). canadiantire. Retrieved from https://www.instagram.com/canadiantire/.

Coelho, R.L.F., de Oliveira, D.S., \& de Almeida, M.I.S. (2016). Does Social Media Matter for Post typology? Impact of Post Content on Facebook and Instagram metrics. Online Information Review, 40(4), 458-471.

CVS Health Corporation. (2017, 22 January). cvspharmacy. Retrieved from https://www.instagram.com/cvspharmacy/.

Décathlon S.A. (2017, 22 January). decathlones. Retrieved from https://www.instagram.com/decathlones/.

Deloitte Touche Tohmatsu Limited (2017). Global powers of retailing. Retrieved from https://www2.deloitte.com/content/dam/Deloitte/global/Documents/consumerindustrial-products/gx-cip-2017-global-powers-of-retailing.pdf.

Dick's Sporting Goods, Inc. (2017, 22 January). dickssportinggoods. Retrieved from https://www.instagram.com/dickssportinggoods/.

dm-drogerie markt GmbH + Co. KG. (2017, 22 January). dm_deutschland. Retrieved from https://www.instagram.com/dm_deutschland/.

Foot Locker, Inc. (2017, 22 January). footlocker. Retrieved from https://www.instagram.com/footlocker/.

GameStop Corp. (2017, 22 January). gamestop. Retrieved from https://www.instagram.com/gamestop/.

H \& M Hennes \& Mauritz AB. (2017, 22 January). hm. Retrieved from https://www.instagram.com/hm/.

Inditex, S.A. (2017, 22 January). zara. Retrieved from https://www.instagram.com/zara/

Instagram, (2016, 15 December). 600 Million and counting. Retrieved from http://blog.instagram.com/post/154506585127/161215-600million.

Kering S.A. (2017, 22 January). kering_official. Retrieved from https://www.instagram.com/kering_official/.

Lowe's Companies, Inc. (2017, January 22). loweshomeimprovement. Retrieved from https://www.instagram.com/loweshomeimprovement/.

L Brands, Inc. (2017, 22 January). lasenza. Retrieved from https://www.instagram.com/lasenza/.

LVMH Moët Hennessy-Louis Vuitton S.A. (2017, 22 January). lvmh. Retrieved from https://www.instagram.com/lvmh/.

Malhotra, N.K. (2010). Marketing research: An applied orientation: Global Edition. $6^{\text {th }}$ edition. Upper Saddle River: N.J., Pearson Education.

Manikonda, L., Venkatesan, R., Kambhampati, S., \& Li, B. (2015). Evolution of fashion brands on Twitter and Instagram. arXiv:1512.01174v1 [cs.SI]. Retrieved from 
https://www.researchgate.net/publication/285647713_Evolution_of_fashion_brand s_on_Twitter_and_Instagram.

PetSmart, Inc. (2017, 22 January). petsmart. Retrieved from https://www.instagram.com/petsmart/.

Rite Aid Corporation. (2017, 22 January). riteaid. Retrieved from https://www.instagram.com/riteaid/.

Staples, Inc. (2017, 22 January). staples. Retrieved from https://www.instagram.com/staples/.

The Gap, Inc. (2017, 22 January). gap. Retrieved from https://www.instagram.com/gap/

The Home Depot, Inc. (2017, 22 January). homedepot. Retrieved from https://www.instagram.com/homedepot/.

The IKEA Group (INGKA Holding B.V.). (2017, 22 January). ikeausa. Retrieved from https://www.instagram.com/ikeausa/.

The TJX Companies, Inc. (2017, 22 January). tjmaxx. Retrieved from https://www.instagram.com/tjmaxx/.

Walgreens Boots Alliance, Inc. (2017, 22 January). walgreens. Retrieved from https://www.instagram.com/walgreens/. 